\title{
Successful Management of Carbamate Poisoning among Children: Case Report from Gaza Strip
}

\author{
Yasser El-Nahhal \\ Faculty of Science, The Islamic University of Gaza, Gaza City, Palestine \\ Email: y_el_nahhal@hotmail.com
}

How to cite this paper: El-Nahhal, Y. (2018) Successful Management of Carbamate Poisoning among Children: Case Report from Gaza Strip. Occupational Diseases and Environmental Medicine, 6, 95-106.

https://doi.org/10.4236/odem.2018.63008

Received: June 26, 2018

Accepted: August 11, 2018

Published: August 14, 2018

Copyright $\odot 2018$ by author and Scientific Research Publishing Inc. This work is licensed under the Creative Commons Attribution International License (CC BY 4.0).

http://creativecommons.org/licenses/by/4.0/

\begin{abstract}
A bad management of pesticide marketing and use resulted in using extreme toxic pesticides inside houses for controlling public health insects such as cockroaches. A child of two years old was poisoned with pesticide residues after application of pesticides at home for cockroach control. The child with a semi-conscious status was brought to the European hospital in south Gaza with his father along with the empty container of pesticide which was used at home. It appeared that Carbaryl (a carbamate insecticide) was the reason for poisoning. In the intensive care unite the child was washed out with clean water and his cloths were removed to reduced the possible hazards. Blood analysis showed that moderate inhibition of acetylcholinesterase (AChE) on addition became more sever on due time. Then the child was given several doses of atropine but without any improvement in AChE activity. Then the child was given Obedoxim as an antidote. This resulted in significant improvement of AChE activity. The child continued to receive Obedoxim every day until AChE activity reached the normal range. Blood analysis did not show any traces of Carbaryl. It is recommended to give Obedoxim to the carbamate immediately when someone is poisoned instead of atropine for successful management of the poisoned case.
\end{abstract}

\section{Keywords}

Carbaryl, Insecticides, Poisoned Case, Obedoxim, Atropine

\section{Introduction}

Pesticide poisoning in Gaza became quite common due to bad management of pesticide poisoning. However, poisoning in Gaza was occurred due to occupa- 
tional activity of pesticides such as application of pesticides in farms and/or in houses [1] [2] [3].

Recent reports showed the use of pesticide container as a domestic tool among farm community. This attitude may expose the farm community to health risks such as occurrence of poisonous case among farmers [4]. So far toxicity of pesticides among population in Gaza has been documented. For instance long term toxicity [5] [6] [7], acute toxicity [8], accidental toxicity [9], and suicidal attempts [10].

In addition, application of pesticides has been shown to disrupt the ecosystem, for instance damage to: cyanobacteria [11]-[16], plants [17], fish [18] [19], and chicken [20]. Furthermore, toxicity of carbamate insecticides among population has been documented. For instance associations between pesticide use and haematological cancer risk [21], neurotoxic effects [22], decreased semen quality [23] [24], pathologically aspects such as proven interstitial pneumonitis after resolution of initial pulmonary edema [25].

It is obvious that the abovementioned work poorly investigated the toxicity among children, or the investigation of toxicity among children remains on its primary stages. Furthermore, it is urgently needed to document a case of poising among children to be a scientific guide for successful management for poisoning among children around the world. Therefore, the author of this study devoted his efforts to present a poisonous case among children below three years old.

\section{Case Report}

Mr. Angheem A, a young child, 3 years old, losing conciousness at home while his father was spaying Carbaryl (an insecticide) in the house garden using ultra low volume technique. The father brought the child to the European hospital at 4:50 PM with a history of semi-conciousness. It appeared that the father used ultra-low volume technique at a windy day.

Carbaryl is an insecticide, belonging to the chemical group carbamate compounds. It has the following chemical name: 1-naphthalenyl-methylcarbamate. Its chemical structure is shown in Figure 1. It is poorly soluble in water $(120 \mathrm{mg} / \mathrm{L})$ and highly soluble in organic solvents [26]. The lethal dose that is required to kill $50 \%$ of the tested organism (LD50) varies according to the tested animal. It is classified as class II of toxicity [27]. So far its long term application has been shown to create health problems among farmers [28].

The child was admitted in the intensive care unit (ICU) where physical investigations such as blood pressure, temperature, and oxygen saturation were measured

Atropine

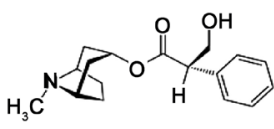

Obedoxim

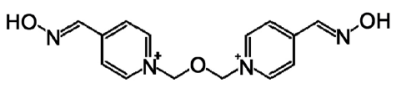

Carbaryl

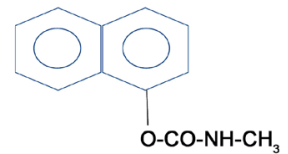

Figure 1. Chemical structure of Atropine, Obedoxim and Carbaryl (data obtained from Internet and [26]). 
immediately. Blood samples were contentiously collected from the patient for complete blood chemistry (CBC) and acetylcholinesterase (AChE) activity were determined according to the international well know Ellman method [29].

\section{Medical Treatment}

The poisonous case was managed following the procedure described by Palestinian Authority Ministry of Health [30]. In this protocol, the cloths of child were removed and his skin was washed with warm water containing some soups to enhance removal of poison residue from the skin. Then gastric lavage was not conducted because the child was unconscious. Then blood samples were collected for complete blood chemical analysis, and for acetylcholinesterase (AChE) activity determination and for liver enzymes. These steps were repeated every day to monitor the level of AChE. The child was given $10 \mathrm{mg}$ atropine in $500 \mathrm{~mL}$ normal saline solution every $6 \mathrm{~h}$, at a late stage double dose of Atropine was given to the patient. After three days stay in the ICU, the patient was given $75 \mathrm{mg} \mathrm{Ob}$ edoxim in $50 \mathrm{~mL}$ saline solution every $6 \mathrm{hr}$ along with other medical drugs (Diclofen $(75 \mathrm{mg})$ intra muscular injection; Cefazoline (100 mg/8 hr); Zantac (50 mg/8 $\mathrm{hr})$; Intra venues injection; Pramine $(10 \mathrm{mg} / 12 \mathrm{hr})$; Intra venues injection; Obedoxim $(75 \mathrm{mg} / 50 \mathrm{~mL}))$ to stop the clinical symptoms such as vomiting, diarrhea.

\section{Results}

Table 1 shows values of some blood parameters from time of admission in the ICU on $9 / 2 / 2018$ up to the release date from the hospital on 24/2/2018. Comparing with the reference range, it appeared that HGB is reduced from 10.1 on

Table 1. Selected blood indices during the medical treatment of the child.

\begin{tabular}{cccccc}
\hline Parameter & $9 / 2 / 2018$ & $13 / 2 / 2018$ & $15 / 2 / 2018$ & $24 / 2 / 2018$ & ref range \\
\hline HGB $(\mathrm{g} / \mathrm{dL})$ & 10.1 & 9.1 & 8.8 & 8.4 & $12-16 \mathrm{mg}$ \\
$\mathrm{WBC}\left(10^{3} / \mathrm{mm}^{3}\right)$ & 7.8 & 4.8 & 6.2 & 9.2 & $4.5-13.5$ \\
$\mathrm{RBC}\left(10^{6} / \mathrm{\mu L}\right)$ & 4.73 & 4.4 & 4.15 & 3.67 & $4.5-5.3$ \\
$\mathrm{MID}$ & 0.8 & 0.6 & 0.9 & 0.8 & $0-1.8$ \\
$\mathrm{HCT}(\%)$ & 33.4 & 30.4 & 29.6 & 26.5 & $37-49$ \\
$\mathrm{MCH}$ & 21.4 & 20.7 & 21.2 & 22.9 & $25-35$ \\
$\mathrm{RDW}$ & 16.7 & 18.1 & 16.7 & 17.6 & $11.5-14.5$ \\
$\mathrm{MPV}$ & 8.6 & 9 & 9 & 7.4 & - \\
$\mathrm{LYM}$ & 4.9 & 1.7 & 2.3 & 3.4 & $0.6-4.1$ \\
$\mathrm{GRAN}$ & 2.1 & 2.5 & 3.1 & 5 & $2.0-4.1$ \\
MCV & 70.7 & 69.2 & 71.3 & 72.2 & $78-102$ \\
MCHC & 30.2 & 29.9 & 29.7 & 31.7 & $31-37$ \\
PLT (10 $\left./ 0^{3} \mathrm{~mm}^{3}\right)$ & 362 & 241 & 404 & 558 & $140-450$ \\
Glucose & 104 & & 72 & 76 & $80-120$ \\
\hline
\end{tabular}

Foot note: $\mathrm{HGB}=$ hemoglobin; where $\mathrm{WBC}=$ white blood count; $\mathrm{RBC}=$ red blood count; $\mathrm{HCT}=$ hematocrit; $\mathrm{MCH}=$ mean corpuscular hemoglobin; RDW = red blood distribution percent; LYM = lymphocyte cell percent; GRAN = granulocyte cell percent; $\mathrm{MCV}=$ mean corpuscular volume; $\mathrm{MCHC}=$ mean corpuscular hemoglobin concentration; PLT = platelet count. 
admission date to acceptable reference range. So far, similar trends were observed with other blood parameters such as WBC, RBC, HCT.

On the other hand, Figure 2 shows the inhibition status of acetylcholine esterase $(\mathrm{AChE})$. Three stages of AChE activity levels were characterized. These stages are: stage $a$, stage $b$ and stage $c$, where stage a shows low level of inhibition, stage $b$ shows the maximum inhibition level and stage $c$ shows the recovery level of the AChE due to treatment with atropine and Obedoxim.

It appeared from these stages that AChE activity was slightly inhibited on admission date then became severely inhibited in due time and reached the maximum inhibition percentage on the seventh day of treatment, then inhibition percentages reduced (Figure 2). So far, the inhibition percentage is reduced to a lower level and reached to the lowest inhibition percentage due to medical treatment with Obedoxim.

On the other hands levels of ALT, AST and ALP were reduced from high levels 29,66 , and $484 \mathrm{u} / \mathrm{L}$ to lower levels $14,35,326 \mathrm{u} / \mathrm{L}$ respectively. These data indicated that Carbaryl inhibit the production of these enzyme.

\section{Discussion}

Carbaryl is an insecticide widely used in the field and at home for many species of insect control. It belongs to carbamate compound, a class of insecticides derived from the amid radical of carbonic acid [26]. Carbaryl is used in many countries without any restriction. It can be applied by either ultra-low volume technique or high-volume technique but both techniques are recommended for

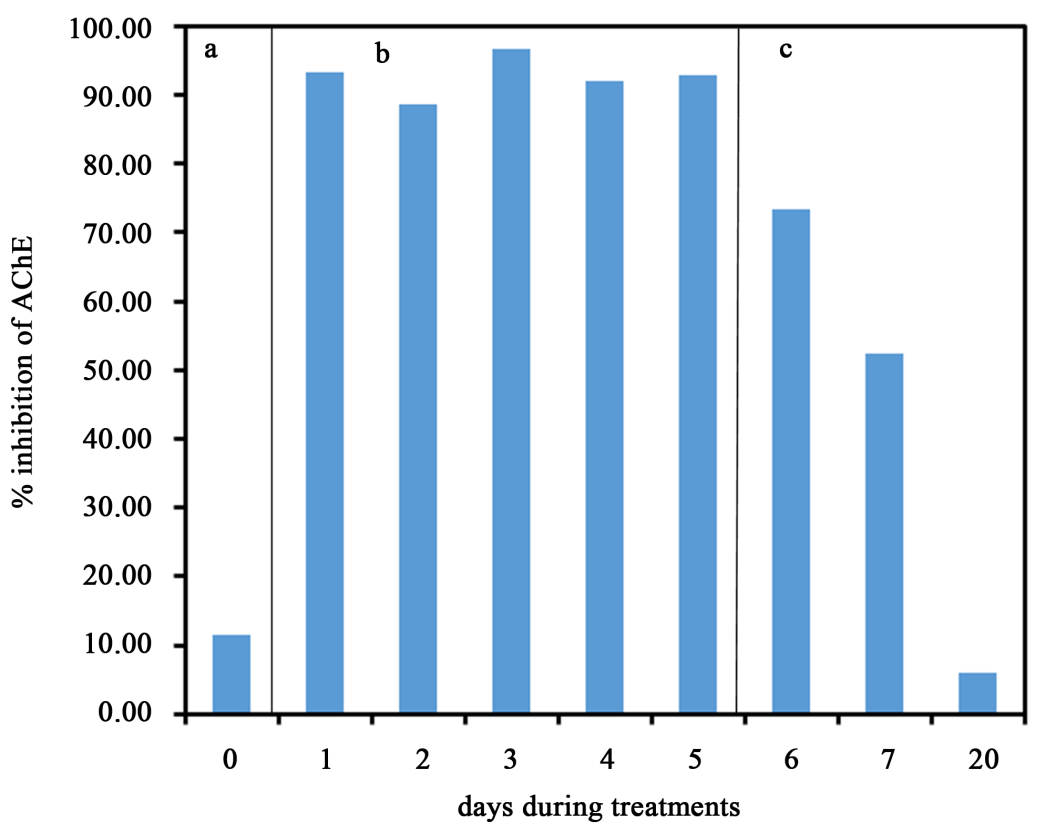

Figure 2. AChE activity levels. Phase a, b and c represent the initial status of AChE on admission time (few hours after poisoning), maximum inhibition level and recovery level, respectively. Percentage of AChE inhibitions were $11.4 ; 96.72 \%$ and $52.5 \%$ for the status on admission, maximum inhibition and recovery respectively. 
field applications. So far, ultra-low technique is a very dangerous method because it directly used the technical materials of Carbaryl without and water dilution. This technique may result in high atmospheric contamination of Carbaryl drift that may cause serious poisoning cases among population specially in the crowded areas or in houses closed to the rural areas where ultra-low volume technique are being applied. This is in accordance with El-Nahhal et al. [31] [32] who found that drift of pesticide application using ultra low volume technique, in which it caused harmful effects to non-target organisms. In addition, ultra-low volume technique used the organic solvent to dissolve the technical materials of Carbaryl. This further enhanced the fast distribution of Carbaryl on the skin of poisoned cases. This agreed with Tomlin [26] who reported similar phenomenon. Furthermore, the data in Figure 1 clearly shows the chemical structure of Carbaryl, Atropine and Obedoxim contained aromatic groups. This property enables planar distribution of molecules and faster reaction with AChE. Additionally, it can be suggested that Carbaryl reacted with AChE producing a complex reaction type 2 [33]. This is in accordance with the data in Table 1, which indicated the possible reaction of between Carbaryl and blood parameters. This is evidenced from the data in Table 1, which showed high values of blood parameter on admission date and reduced to lower values on the release date, regardless to the fact that value of blood parameter is in the acceptable reference range.

Moreover, it can be suggested that Carbaryl can be adsorbed on the surfaces of blood cells from a type of adsorption complex. This suggestion is in accordance with El-Nahhal and Safi [34] [35], who revealed the adsorption of some pesticides on biomaterials. Nevertheless, this type of surface reaction may occur due to chemical structure. This suggestion is in agreement with previous reports [36] [37] [38] which revealed the possibility of surface reactions of organic molecules in biological system. Moreover, El-Nahhal [33] characterized four type of surface reactions between organophosphorus insecticides and enzymes among them ionic interactions (Adsorption reaction).

That data in Figure 2, indicated three stages of poisoning. These are, stage a, low inhibition percentage, stage $b$, the highest inhibition percentage and stage $c$, reduced inhibition percentage (recovery stage). The explanation of these results is that, stage a indicates the distribution, partitioning and activation of Carbaryl molecules in the human body. Stage b indicated the formation of Carbaryl AChE complex due to reaction of activated Carbaryl molecules and AChE. Stage $c$ indicated the degradation of Carbaryl AChE complex and formation of free AChE (recovery of poisoning). This explanation is in agreement with previous reports [1] [4] [10].

Exposure to Carbaryl molecules and its reaction with $\mathrm{AChE}$, and recovery reactions can be modeled as follows:

$$
\begin{gathered}
\text { Carbary + human body } \rightarrow \text { distribtion partitioning and activation } \\
\text { activated Carbary }+\mathrm{AChE} \rightarrow[\text { Carbary-AChE }] \text { complex }
\end{gathered}
$$




$$
\begin{gathered}
{[\text { Carbary-AChE }]+\text { Atropine } \rightarrow[\text { Carbary-AChE-Atropine }] \text { Ecomplex }} \\
\begin{array}{c}
{[\text { Carbary-AChE }]+\text { Obedoxim } \rightarrow[\text { Carbary-AChE-Obedoxim }] \text { Ecomplex }} \\
{[\text { Carbary-AChE-Obedoxim }] \text { Ecomplex }} \\
\rightarrow[\text { Carbary-Obedoxim }]+\text { AChE free } \\
{[\text { Carbary-Obedoxim }] \rightarrow \text { unine exctreation }}
\end{array}
\end{gathered}
$$

According to these models, Equation (1) represents distribution, partitioning and activation of Carbaryl. This step depends on the physicochemical properties of Carbaryl such as partitioning coefficients (Kow) water solubility. As long as the partitioning of Carbaryl is fast in the human body as long the toxicity appeared. For our case, the distribution of Carbaryl was not so fast accordingly appearance of inhibition was low. This is evidenced in Figure 2.

As long as activated Carbaryl molecules reached the target site (AChE) it reacted with it and formed Carbaryl-AChE complex Equation (2). This complex represents the inhibition status of $\mathrm{AChE}$. As long as the inhibition status is stable, the poisoning case continued to be stronger due to accumulation of acetylcholine in the synaptic gaps and lack of effective medical treatment. As long as the medical treatment is not effective, Equation (3), no improvement would occur. This is obvious from the data in Figure 2, where maximum inhibition was observed for longer period with using atropine. Nevertheless, effective medical treatment as using Obedoxim as in Equations (4) and (5) which resulted in a formation of free AChE. Then Carbaryl-Obedoxim complex would be excreted from the body throughout urine system. This explanation is in accordance with Ref [33] who demonstrated the strength of reactions between pesticides and AChE. So far some chemical reactions are presented in Figure 3. It can be seen that the activated Carbaryl reacted with AChE forming an inhibited status of AChE, which responsible on the appearance of toxicity symptoms due to accumulation of acetylcholine in the synaptic gaps. Then the use of effective antidote Obedoxim is to free AChE from the complex and to excrete Carbaryl from the body.

\section{Environmental Relevance}

Poisoning among population included four types: 1) food poisoning, 2) drug poisoning, 3) pesticides poisoning and 4) poisoning of industrial chemicals. Furthermore, pesticides poisoning may occur via indirect ways such as ingestion of contaminated food [39] [40] [41] [42] [43], contaminated water [44]-[49], contaminated air [50] (Bornstein, 2001) and contaminated soil [51]-[59]. Moreover, the use of ultra-low volume and high volume techniques resulted in many poisoning cases among populations and farmers [1] [2] [3] [4]. Therefore, tremendous efforts have been made to develop safe and effective formulations, this included clay based and/or organo-clay formulations [60]-[68].

\section{Conclusion}

Poisoning with Carbaryl showed three stages of poisoning, distribution and 

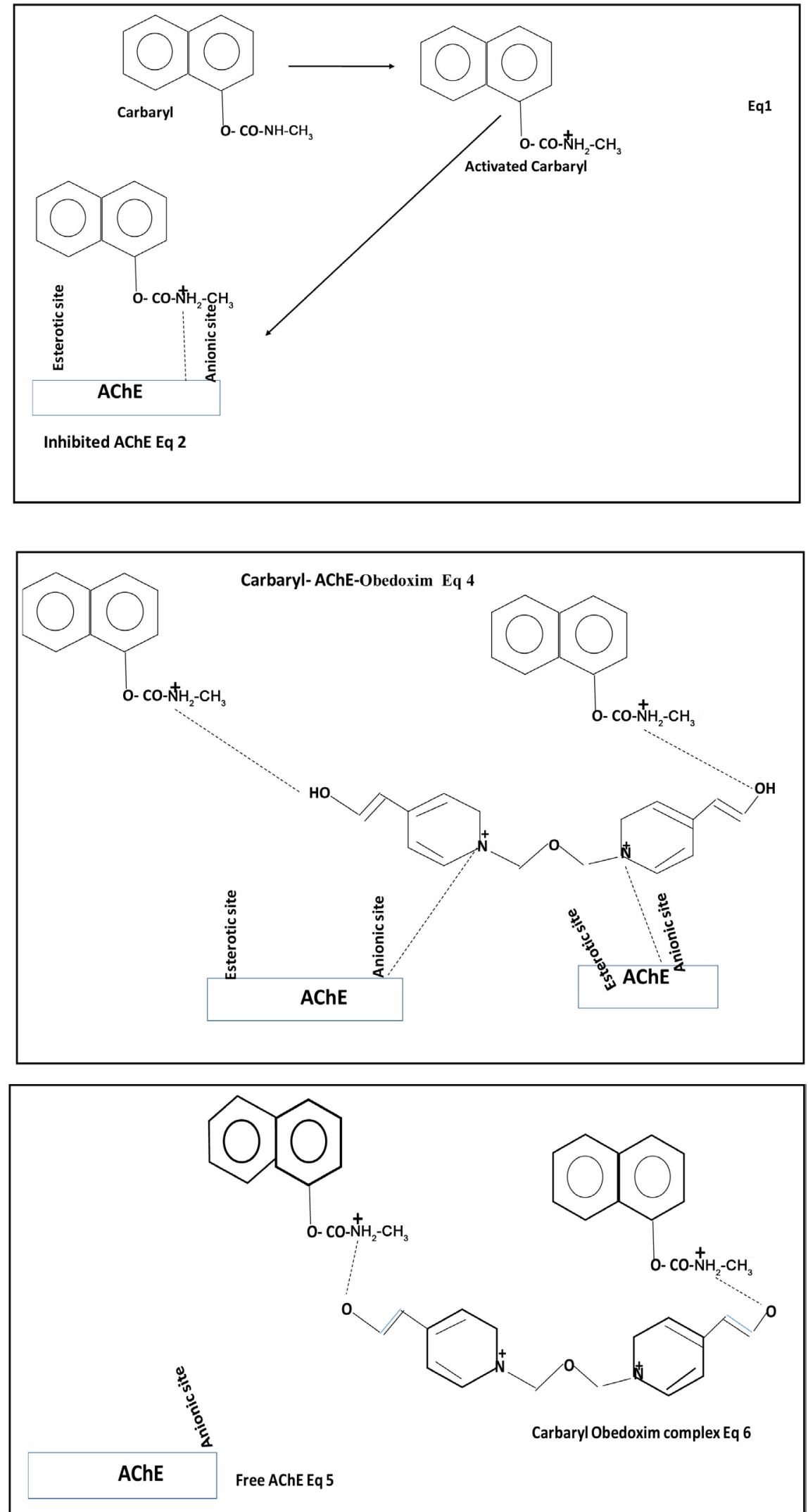

Figure 3. Proposed schematic reactions of Carbaryl and AChE in the poisoned case and recovery reactions with using of Obedoxim. 
activation, inhibition of AChE, and recovery stage. It appeared that atropine was not effective as Carbaryl antidote as Obedoxim showed successful management. Reduction of ALT, AST and ALP production were associated with progress of poisoning case. It is recommended to give more attention to the use of pesticides in house or gardens.

\section{Acknowledgements}

Special thanks to the Alexander von Humboldt foundation for a Research Fellowship at Leipzig University and BAM institute Germany. Special thanks go to my students at faculty of science for helping me analyzing some blood parameters.

\section{Ethical Statement}

This study was not funded by any organization; compliance with Ethical Standards.

\section{Conflict of Interest}

Author declares that he has no conflict of interest. The study comply with the international ethics issues. Consent form was obtained from father of Mr Angheem $\mathrm{A}$.

\section{References}

[1] El-Nahhal, Y. (2017) Risk Factors among Greenhouse Farmers in Gaza Strip. Occupational Diseases and Environmental Medicine, 5, 1-10. https://doi.org/10.4236/odem.2017.51001

[2] El-Nahhal, Y., EL-Dahdouh, N., Hamdona, N. and Alshanti, A. (2016) Toxicological Data of Some Antibiotics and Pesticides to Fish, Mosquitoes, Cyanobacterial Mats and to Plants. Data in Brief, 6, 871-880.

https://doi.org/10.1016/j.dib.2016.01.051

[3] Yasser, E.L.N. and Adli, A. (2015) Toxicity of Single and Mixtures of Antibiotics to Cyanobacteria. Journal of Environmental \& Analytical Toxicology, 5, 274. https://doi.org/10.4172/2161-0525.1000274

[4] El-Nahhal, Y. (2016) Biochemical Changes Associated with Long Term Exposure to Pesticide among Farmers in the Gaza Strip. Occupational Diseases and Environmental Medicine, 4, 72-82. https://doi.org/10.4236/odem.2016.43009

[5] Safi, J., El-Nahhal, Y., Soliman, S.A. and Elsebae, A.H. (1993) Mutagenic and Carcinogenic Pesticides Used in the Gaza Strip Agricultural Environmental. The Science of the Total Environment, 132, 371-380. https://doi.org/10.1016/0048-9697(93)90145-V

[6] El-Nahhal, Y. and Radwan, A. (2013) Human Health Risks: Impact of Pesticide Application. Journal of Environment and Earth Science, 3, 199-209.

[7] El-Nahhal, Y., Wheidi, B. and EL-Kurdi, S. (2016) Development of Ecologically Acceptable Chlorpyrifos Formulation for Effective and Safe Application. Journal of Encapsulation and Adsorption Sciences, 6, 91-108.

https://doi.org/10.4236/jeas.2016.63008

[8] El-Nahhal, Y. (2017) Acute Poisoning among Farmers by Chlorpyrifos: Case Report 
from Gaza Strip. Occupational Diseases and Environmental Medicine, 5, 47-57. https://doi.org/10.4236/odem.2017.52005

[9] El-Nahhal, Y. (2018) Accidental Zinc Phosphide Poisoning among Population: A Case Report. Occupational Diseases and Environmental Medicine, 6, 37-49. https://doi.org/10.4236/odem.2018.62003

[10] El-Nahhal, Y. (2017) Suicidal Attempt Using Racumin: A Case Report from Gaza Strip, Palestine. Open Access Journal of Toxicology, 2, 1-3. https://doi.org/10.19080/OAJT.2017.02.555579

[11] El-Nahhal, Y., Awad, Y. and Safi, J. (2013) Bioremediation of Acetochlor in Soil and Water Systems by Cyanobacterial Mat. International Journal of Geosciences, 4, 880-890. https://doi.org/10.4236/ijg.2013.45082

[12] Safi, J., Awad, Y. and El-Nahhal, Y. (2014) Bioremediation of Diuron in Soil and by Cyanobacterial Mat. American Journal of Plant Sciences, 5, 1081-1089. https://doi.org/10.4236/ajps.2014.58120

[13] El-Nahhal, Y. and EL-Dahdouh, N. (2015) Toxicity of Amoxicillin and Erythromycin to Fish and Mosquito. Ecotoxicology and Environmental Contamination, 10, 13-21. https://doi.org/10.5132/eec.2015.01.03

[14] EL-Nahhal, Y. and Alshanti, A. (2015) Toxicity of Single and Mixtures Antibiotics to Cyanobacteria. Journal of Environmental \& Analytical Toxicology, 5, 1-8. https://doi.org/10.4172/2161-0525.1000274

[15] EL-Nahhal, Y., Kerkez, M.F.S. and Abu Heen, Z. (2015) Toxicity of Diuron, Diquat and Terbutryn Cyanobacterial Mats. Ecotoxicology and Environmental Contamination, 10, 71-82. https://doi.org/10.5132/eec.2015.01.11

[16] Ma, J., Tong, S., Wang, P. and Chen, J. (2010) Toxicity of Seven Herbicides to the Three Cyanobacteria Anabaena Flos-Aquae, Microcystis Flos-Aquae and Mirocystis Flos-Aquae and Mirocystis aeruginosa. 4, 347-352.

[17] El-Nahhal, Y. and Hamdona, N. (2015) Phytotoxicity of Alachlor, Bromacil and Diuron as Single or Mixed Herbicides Applied to Wheat, Melon, and Molokhia. SpringerPlus, 4, 364. https://doi.org/10.1186/s40064-015-1148-7

[18] EL-Nahhal, Y., EL-Najjar, Sh. and Afifi, S. (2015). Impact of Organic Contamination on Some Aquatic Organisms. Toxicology International, 22, 45-53. https://doi.org/10.4103/0971-6580.172256

[19] El-Nahhal, Y., Abadsa, M. and Affifi, S. (2014) Leaching Potential of Diuron and Linuron in Gaza Soils. American Journal of Plant Sciences, 5, 4040-4049. https://doi.org/10.4236/ajps.2014.526422

[20] El-Nahhal, Y. and Lubbad, R. (2018) Acute and Single Repeated Dose Effects of Low Concentrations of Chlorpyrifos, Diuron, and Their Combination on Chicken. Environmental Science and Pollution Research, 25, 10837-10847. https://doi.org/10.1007/s11356-018-1313-y

[21] Presutti, R., Harris, S.A., Kachuri, L., Spinelli, J.J., Pahwa, M., Blair, A., Zahm, S.H., Cantor, K.P., Weisenburger, D.D., Pahwa, P., McLaughlin, J.R., Dosman, J.A. and Freeman, L.B. (2016) Pesticide Exposures and the Risk of Multiple Myeloma in Men: An Analysis of the North American Pooled Project. International Journal of Cancer, 139, 1703-1714. https://doi.org/10.1002/ijc.30218

[22] Lee, I., Eriksson, P., Fredriksson, A., Buratovic, S. and Viberg, H. (2015) Developmental Neurotoxic Effects of Two Pesticides: Behavior and Biomolecular Studies on Chlorpyrifos and Carbaryl. Toxicology and Applied Pharmacology, 288, 429-438. https://doi.org/10.1016/j.taap.2015.08.014 
[23] Meeker, J.D., Ryan, L., Barr, D.B., Herrick, R.F., Bennett, D.H., Bravo, R. and Hauser, R. (2004) The Relationship of Urinary Metabolites of Carbaryl/Naphthalene and Chlorpyrifos with Human Semen Quality. Environmental Health Perspectives, 112, 1665-1670. https://doi.org/10.1289/ehp.7234

[24] Hori, Y., Nakajima, M., Fujisawa, M., Shimada, K., Hirota, T. and Yoshioka, T. (2002) Simultaneous Determination of Propanil, Carbaryl and 3,4-Dichloroaniline in Human Serum by HPLC with UV Detector Following Solid Phase Extraction. Yakugaku Zasshi, 122, 247-251. https://doi.org/10.1248/yakushi.122.247

[25] Park, C.H., Kim, K., Park, S.K. and Lee, C.H. (2000) Carbamate Poisoning: High Resolution CT and Pathologic Findings. Journal of Computer Assisted Tomography, 24, 52-54. https://doi.org/10.1097/00004728-200001000-00010

[26] Tomlin, C. (2000) The Pesticide Manual. British Crop Protection Council.

[27] WHO Library Cataloguing-in-Publication Data (2009) World Health Organization Recommended Classification of Pesticides by Hazard and Guidelines to Classification.

[28] Sievert, J.S., Morrissey, B.F. and Calvert, G.M. (2013) Severe Acute Illness in a Toddler Exposed to Multiple Agricultural Pesticides and an Insect Repellent. Journal of Agromedicine, 18, 285-292. https://doi.org/10.1080/1059924X.2013.826606

[29] Ellman, G.L., Courtney, K.D., Andres, V. and Feather-Stont, R.M. (1961) A New and Rapid Colorimetinc Determination of Acetylcholinesterase Activity. Biochemistry and Pharmacology, 7, 88-95. https://doi.org/10.1016/0006-2952(61)90145-9

[30] Palestinian National Authority Ministry of Health (2004) Postpartum Care Protocols.

[31] El-Nahhal, Y., Nir, S., Margulies, L. and Rubin, B. (1999) Reduction of Photodegradation and Volatilization of Herbicides in Organo-Clay Formulations. Applied Clay Science, 14, 105-119. https://doi.org/10.1016/S0169-1317(98)00053-2

[32] El-Nahhal, Y. (2018) Reactions of Acetylcholinesterase with Organophosphorus Insecticides. Journal of Pharmacology \& Clinical Toxicology, 6, 1108.

[33] El-Nahhal, Y. and Safi, J. (2004) Adsorption Behavior of Phenanthrene on Organoclays under Different Salinity Levels. Journal of Colloid and Interface Science, 269, 265-273. https://doi.org/10.1016/S0021-9797(03)00607-6

[34] El-Nahhal, Y. and Safi, J. (2004) Stability of an Organo Clay Complex: Effects of High Concentrations of Sodium Chloride. Applied Clay Science, 24, 129-136. https://doi.org/10.1016/j.clay.2003.01.002

[35] El-Nahhal, Y. (2003) Adsorption Mechanism of Chloroacetanilide Herbicides to Modified Montmorillonite. Journal of Environmental Science and Health B, 38, 591-604. https://doi.org/10.1081/PFC-120023517

[36] El-Nahhal, Y. (2003) Persistence, Mobility, Efficacy and Safety of Chloroacetanilide Herbicide Formulation under Field Conditions. Environmental Pollution, 124, 33-38. https://doi.org/10.1016/S0269-7491(02)00431-1

[37] El-Nahhal, Y. (2003) Adsorptive Behavior of Acetochlor on Organoclay Complexes. Bulletin of Environmental Contamination and Toxicology, 70, 1104-1111. https://doi.org/10.1007/s00128-003-0096-z

[38] El-Nahhal, Y., Nir, S., Polubesova, T., Margulies, L. and Rubin, B. (1998) Leaching, Phytotoxicity and Weed Control of New Formulations of Alachlor. Journal of Agricultural Food Chemistry, 46, 3305-3313. https://doi.org/10.1021/jf971062k

[39] Schecter, A., Papke, O., Ryan, J., Furst, P., Isaac, J., Hrimat, N., Neiroukh, F., Safi, J., El-Nahhal, Y., Abu El-Haj, S., Avni, A., Richter, E., Chuwers, P. and Fischbein, A. 
(1997) Dioxins, Dibenzofurans and PCBs in Human Blood, Human Milk and Food from Israel, the West Bank and Gaza. Organohalogen Compounds, 33, 457-461.

[40] Schecter, A., Papke, O., Isaac, J., Hrimat, N., Neiroukh, F., Safi, J. and El-Nahhal, Y. (1997) 2,3,7,8 Chlorine Substituted Dioxins and Dibenzofuran Congeners in 2,4-D, 2,4,5-T and Pentachlorophenol. Organohalogen Compounds, 32, 51-55.

[41] Safi, J., Abu Foul, N., El-Nahhal, Y. and El-Sebae, A. (2002) Monitoring of Pesticide Residues on Cucumber, Tomatoes and Strawberries in Gaza Governorates, Palestine. Nahrung/ Food, 46, 34-49.

[42] El-Nahhal, Y. (2004) Contamination and Safety Status of Plant Food in Arab Countries. Journal of Applied Science, 4, 411-417. https://doi.org/10.3923/jas.2004.411.417

[43] El-Nahhal, Y. (2018) Nitrate Residues in Fruits, Vegetables and Bread Samples and Their Health Consequences. Health, 10, 487-501. https://doi.org/10.4236/health.2018.104039

[44] El-Nahhal, Y. (2006) Contamination of Groundwater with Heavy Metals in Gaza. 10 th International Water Technology Conference, Alexandria, 1139-1150.

[45] El-Nahhal, Y. and Safi, J. (2008) Removal of Pesticide Residues from Water by Organo-Bentonites. 12th International Water Technology Conference, Alexandria, 1711-1724.

[46] El-Nahhal, Y. and Harrarah, S. (2013) Contamination of Groundwater and Associated Disease: Case Study from Khan Younis Governorate, Gaza, PNA. Journal of Environment and Earth Science, 3, 147-153.

[47] Al-Arifi, S.N., Al-Agha, R.M. and El-Nahhal, Z.Y. (2013) Hydrogeology and Water Quality of Umm Alradhma Aquifer, Eastern Saudi Arabia. Journal of Environment and Earth Science, 3, 118-127.

[48] Al-Kurdi, S., Al-Louh, M.O., Al-Agha, M.R. and El-Nahhal, Y. (2018) Development of Analytical Method for the Detection of Nemacur Residues in Cucumber Fruits. American Journal of Analytical Chemistry, 9, 64-76. https://doi.org/10.4236/ajac.2018.91006

[49] Al-Arifi, S.N., Al-Agha, R.M. and El-Nahhal, Z.Y. (2013) Environmental Impact of Landfill on Groundwater, South East of Riyadh, Saudi Arabia. Journal of Natural Sciences Research, 3, 222-242.

[50] Bornstein, R., Safi, J., El-Nahhal, Y., Isaac, J., Rishmawi, Kh., Luria, M., Mahrer, Y. and Weinroth, E. (2001) Transboundary Air-Quality Effects from Urbanization.

[51] El-Nahhal, Y., Nir, S., Serban, S., Rabinowitz, O. and Rubin, B. (2001) Organoclay Formulation of Acetochlor for Reduced Movement in Soil. Journal of Agricultural and Food Chemistry, 49, 5464-5371. https://doi.org/10.1021/jf010561p

[52] El-Nahhal, Y., Undabeytia, T., Polubesova, T., Golda Mishael, Y., Nir, S. and Rubin, B. (2001) Organo-Clay formulations of Pesticides: Reduced Leaching and Photodegradation. Applied Clay Science, 18, 309-326. https://doi.org/10.1016/S0169-1317(01)00028-X

[53] Nir, S., Undabeytia, T., Yaron, D., El-Nahhal, Y., Polubesova, T., Serban, S., Rytwo, G., Lagaly, G. and Rubin, B. (2000) Optimization of Adsorption of Hydrophobic Herbicides on Montmorillonite Preadsorbed by Monovalent Organic Cations: Interaction between Phenyl Rings. Environmental Science and Technology, 34, 1269-1274. https://doi.org/10.1021/es9903781

[54] El-Nahhal, Y., Nir, S., Serban, C., Rabinowitz, O. and Rubin, B. (2000) Montmorillonite-Phenyltrimethylammounium Yields Environmentally Improved Formula- 
tions of Hydrophobic Herbicides. Journal of Agricultural and Food Chemistry, 48, 4791-4801. https://doi.org/10.1021/jf000327j

[55] El-Nahhal, I., Al-Najar, H. and El-Nahhal, Y. (2014) Cations and Anions in Sewage Sludge from Gaza Waste Water Treatment Plant. American Journal of Analytical Chemistry, 5, 655-665. https://doi.org/10.4236/ajac.2014.510073

[56] El-Nahhal, Y., Nir, S., Polubesova, T., Margulies, L. and Rubin, B. (1997) Organo-Clay Formulations of Alachlor: Reduced Leaching and Improved Efficacy. Proceedings of Brighton Crop Protection Conference, Weeds, Vol. 1, 21-26.

[57] El-Nahhal, Y. and Lagaly, G. (2005) Salt Effects on the Adsorption of a Pesticide on Modified Bentonite. Colloid and Polymer Science, 283, 968-974.

https://doi.org/10.1007/s00396-004-1244-7

[58] El-Nahhal, Y. and Safi, J. (2005) Adsorption of Benzene and Naphthalene to Modified Montmorillonite. Journal of Food, Agriculture and Environment, 3, 295-298.

[59] El-Nahhal, Y., Lagaly, G. and Rabinovitz, O. (2005) Organo-Clay Formulations of Acetochlor: Effect of High Salt. Journal of Agricultural and Food Chemistry, 53, 1620-1624. https://doi.org/10.1021/jf040383a

[60] Alloh, M.O., AL-Kurdi, S., Alagha, M.R. and Yasser, E.-N. (2018) Nemacur Residue Analysis in Soil Water and Cucumber Samples Collected from the Field in Gaza Strip, Palestine. American Journal of Plant Sciences, 9, 517-530. https://doi.org/10.4236/ajps.2018.93039

[61] Nir, S., Undabeytia, T., Yaron-Marcovich, D., El-Nahhal, Y., Polubesova, T., Serban, C., Rytwo, G., Lagaly, G. and Rubin, B. (1999) Optimizing Adsorption of Hydrophobic Herbicides on Organo-Clays. The 14th International Plant Protection Congress, Jerusalem, 25-30 July 1999, 12.

[62] Rubin, B., El-Nahhal, Y., Nir, S. and Margulies, L. (2001) Slow Release Formulations of Pesticides. Patent No. US6,261,997 B1.

[63] Abed, M.A., Safi, M.N., Köster, J., Beer, D., El-Nahhal, Y., Rullkötter, J. and Garcia-Pichel, F. (2002) Microbial Diversity of a Heavily Polluted Microbial Mat and Its Community Changes Following Degradation of Petroleum Compounds. Applied Environmental Microbiology, 68, 1674-1683. https://doi.org/10.1128/AEM.68.4.1674-1683.2002

[64] El-Nahhal, Y. (2013) Alcohol Like Syndrome: Influence of Increased $\mathrm{CO}_{2}$ Concentration in the Respiration Air. Journal of Environment and Earth Science, 3, 222-227.

http://citeseerx.ist.psu.edu/viewdoc/download?doi=10.1.1.850.9753\&rep=rep1\&type $=\mathrm{pdf}$

[65] El-Nahhal, I., Al-Najar, H. and El-Nahhal, Y. (2014) Physicochemical Properties of Sewage Sludge from Gaza. International Journal of Geosciences, 5, 586-594. https://doi.org/10.4236/ijg.2014.56053

[66] El-Nahhal, Y. (2014) Development of Controlled Release Formulations of Thiabendazole. Journal of Agricultural Chemistry and Environment, 3, 1-8. https://doi.org/10.4236/jacen.2014.31001

[67] El-Nahhal, Y. (2018) Toxicity of Some Aquatic Pollutants to Fish. Environmental Monitoring and Assessment, 190, 449. https://doi.org/10.1007/s10661-018-6830-0

[68] El-Nahhal, Y., Nir, S., Polubesova, T., Margulies, L. and Rubin, B. (1999) Movement of Metolachlor in Soil: Effect of Organo-Clay Formulation. Pesticide Science, 55, 857-864. https://doi.org/10.1002/(SICI)1096-9063(199908)55:8<857::AID-PS24>3.0.CO;2-P 